\title{
Phatic and Politeness on Women's Communication in Facebook: Humanistic Teaching Perspective of Being Polite in Social Media
}

\author{
Rosita Ambarwati \\ Universitas Sebelas Maret, Indonesia \\ e-mail:paramithagita@yahoo.co.id
}

\author{
Joko Nurkamto \\ Universitas Sebelas Maret, Indonesia \\ e-mail: jokonurkamto@gmail.com
}

\author{
Riyadi Santosa \\ Universitas Sebelas Maret, Indonesia \\ e-mail: Riyadisantosa1960@gmail.com
}

\begin{abstract}
:
Technological developments have a wide impact on many things, one of which is the development of communication through social networking. The interesting thing about the Facebook phenomenon is that most of the users are women. Women who are identical with polite behavior are very interesting to study. This study aims to (1) Identify the form of women's phatic speech acts on Facebook. (2) Describe the politeness strategy of women's communication on Facebook, (3) to dig deeper into the extent of women politeness in Facebook through the humanistic teaching perspective. This research is descriptive qualitative research using pragmatic approach. The subjects of the study were women aged 25-50 years. Data is female speech on Facebook social networking. Data selection is done with certain consideration using purposive sampling. Data were collected using a method of referring and noting to a number of speeches containing a form of phatic expression. Test the validity of data is done through credibility test that is by extension of observation and member check. Data analysis was done based on Spradley's analysis model which was divided into 4 stages, namely domain analysis, taxonomic analysis, contextual analysis and cultural theme analysis. The results achieved are: (1) The form of phatic expressions seen from the analysis of speech acts in which the act of speech phatic ranked highest. (2) The characteristics of visible women language are, using polite expression, using indirect sentences, using adjectives, using question tags and humor. (3) The dominant function of the phatic is to maintain friendship and harmony of relationships. (4) Internet-based communication media provide flexibility for women to interact and establish relationships. (5) phatic communication on Facebook becomes dominant because the form of communication is not face to face directly so that the expression of the speaker cannot be seen and the comments that appear cannot be determined time so that the honesty of the less acceptable speech. This has a tendency as a form of introducing space. The women communication in Facebook through the phatic speech acts can be a source of learning approach to be polite in uttering utterances.
\end{abstract}

Keywords: humanistic teaching perspective, phatic, politeness, speech acts, social media 


\section{Introduction}

The development of increasingly diverse and sophisticated communication media provides various conveniences in life especially in terms of interaction with others. One of the most rapid communication phenomena today is the increasing number of social media. These developments will inevitably lead to a variety of changes, turmoil and new phenomena, one of which is the phenomenon of language. Social media is a new media operates the internet applications that allows for the creation and exchange of user-generated contents (Valentini \& Kruckeberg, 2012). The hypertextuality of social media spreads the information fast. It creates live experiences of human beings that lead to the economics, cultural patterns, interactional styles and other aspects of human society (Castells, 2000). People communicate not only limited to one or two people but it can be tens or even hundreds of people. It is certain that such interaction is interesting because the communication is done by several persons in the same subject and social backgrounds and different cultures. Therefore, Social media can weaken or strengthen the intensity of the relationship between people and community (Wellman \& Hampton, 1999).

Facebook is one of the most accessible social media, Mark Zuckerberg creates it to bring people together with different backgrounds and encourage interaction. People tend to use Facebook to maintain a close relationship. They keep in touch with their family, friends, and colleges without need much time. It is in line with Rosen et al opinion, "People from collectivistic cultures utilize social network sites to maintain close relationships with a small number of ties instead of creating new connections with people. One interesting thing about the Facebook phenomenon is most users are women. Pew Research Centre states that more women use social networks, and social networks are most often used is Facebook. The latest data released by Facebook by the end of January 2012, Facebook users in Indonesia in early 2012 showed $40.6 \%$ of the total 43 million users are women (Duggan \& Smith, 2013). It is the most popular social media with a growing membership and young women report spending around two hours per day on Facebook (Fardouly \& Vartanian, 2015; Tiggemann \& Slater, 2013).

Facebook offers a wide range of very interesting things. The first, Facebook is the largest social networking site in the world. The second, Facebook is simpler than other social networking sites, but the menu is more complete and easy to understand by the beginners. Facebook allows users to find friends who are online so it can start chatting easily. The Third, Facebook providing language translation services are more complete. The fourth, Facebook displays information about the product, jobs, news, entertainment, games (game) is more complete. More and more entrepreneurs are using Facebook as a medium for marketing their products. The use of social media by women is a necessity as a means to demonstrate the existence of themselves as human beings. Abraham Maslow says that by nature man is in need of self-esteem, namely to respect themselves (self-respect) and the respect of others (respect from the other). The use of Facebook arouses women to be good looking and ideal. It is driven by the desire to be recognized as an attractive woman, both in terms of appearance and speech. The need of self-esteem can be fulfilled by posting status, comment or photo.

Women use speech as the main way to develop relationships, so communication becomes the focus of women's friendship. Women communication cannot be separated from the characteristics of the female language. The discussion of women tends to be personal and disclosive with a focus on the details of personal life, society, relationships and feelings (Aries \& 
Johnson, 1983; Reisman, 1990; Wood \& Inman, 1993). Besides, women's talks are expressive and supportive (Aukett, Ritchie, \& Mill, 1988; Wright \& Scanlon, 1991). Communication on Facebook is seen as a relaxed interaction. This is commonly referred to as casual chat. This chat can serve as a tired and entertainment buffer. Speeches spoken by speakers and speech partners tend not to be serious, this is called phatic communication. Miller (2008) said that communication through Facebook is a culture in the digital era that includes the scope of phatic. While Hopkins (2014) argues, "Phatic exchanges -a communication exchange that fulfills a social objective rather than imparting information on social-technologies, such as Facebook and Twitter. Social media and social networks have transformed the communication environment and the way organisations Reviews their managing stakeholder relationships. This means that phatic communication is more aimed at keeping social relationships rather than purely on the delivery of information.

Phatic can make the atmosphere rigid to be fun so it is possible serves as a marker of politeness. Act polite is synonymous with speaking with language etiquette considerations. So the phatic speech can serve as a face saving. It is one of the precious learning. People can learn, feel, evaluate and freely to choose the right way to do something. Moreover, it is closely relate with humanistic teaching perspective. The goal of humanistic education moves beyond cognitive and intellectual education to let in the education of the whole person. It regards personal growth and the growth of creativity and to some extent the self-directed learning. The end of education is the same as the end of psychotherapy: making a fully functioning person. Receptiveness to experience, an existential path of living in which life is ongoing, flexible, adaptive process, and faith in the organism as the foundation for behavior are characteristics of the person who is able to learn and to conform to change (Maples, 1979).

This article will explore the phatic speech act as a marker of politeness through pragmatic study as the implication of humanistic teaching. To conduct this study, it is based on some previous researches there are; (1) Kivran-Swaine, Brody, \& Naaman (2013) with the title of his research "Effect of Gender and Tie Strength on Twitter Interaction". This research examines the relationship between the language, gender and social relation. Quantitatively, his research studies how the gender composition of speaking on his twitter account influences the linguistics style of the message conveyed, (2) Barbulet (2013) describes social media from the Pragmatic point of view. This study analyzes a British newspaper blog with a focus on implicature and context studies, (3) Arévalo (2014), produced research that emoticons are forms of expression that serve as markers of politeness and relationship reinforcement to enhance interaction (joking) and make ironic contributions, (4) Wulandari (2014) research on representative speech acts on Facebook status, (5) Fardouly, Diedrichs, Vartanian, \& Halliwell (2015) with the research title Social Comparisons on Social Media; The impact of Facebook to the development of young women's body image concern and the physical growth of adolescent girls, (6) Locher (2015) who examined the politeness associated with work and discussion on Facebook, (7) Theodoropoulou (2015) with her research the politeness of birthday wishes on Facebook, (8) Ruckel (2012) with the title of their research "Self sexualization in Facebook photographs, body surveillance, and body image, (9) Khatib, Sarem, \& Hamidi (2013) talked humanistic education; concern, implication, and applications, Based on some previous researches it can be assumed that Facebook is very interesting to analyze. This study try to dig the women phatic speech act related 
with politeness strategy, and finally it serves the description of precious teaching concept to be polite in communication on Facebook.

\section{Literature Review}

The humanistic principle is referred to Erickson, Roger and Maslow's ideas. They propose learner to be humanized. According to Wang, Bianchi, \& Raley (2005) people cannot satisfy his basic needs. It will affect to their condition physically and psychologically. It is supported by Lei \& $\mathrm{Wu}$ (2007) that the Humanistic approach, on which humanistic education is based, emphasizes the importance of the inner world of the learner and places the individual's thought, feelings, and emotions at the forefront of all human development.

The theory of humanistic education emerged in the 1970s was based from three philosophical theories, namely: pragmatism, progressivism and existentialism. The main idea of pragmatism in education is nurturing continuity of knowledge with deliberate activity change the environment (Dewey, 1997). Furthermore Humanistic theory assumes that any learning theory is good and can be used, as long as the goal is to humanize human beings, namely achievement self-actualization, self-understanding, and self-realization of people learning optimally (Assegaf, 2011). This opinion in line with Maples (1979) the goal of humanistic education moves beyond cognitive and intellectual education to let in the education of the directed learning. The end of education is the same as the end of psychotherapy: making a fully functioning person. Receptiveness to experience, an existential path of living in which life is ongoing, flexible, adaptive process, and faith in the organism as the foundation for behavior are characteristics of the person who is able to learn and to conform to change.

Adler (1927) and Maslow (1943) paved the way in giving credence to a scientific approach to the role of higher human motives and values in understanding human behavior, rather than ascribing human behavior to unconscious and irrational neuroses or the 'push and pull' of various contingencies of reinforcement (Arnold, 1998). According to Gage \& Berliner (1991) remark that the emphasis upon the value of students rests on the awareness of their dignity and rights as unique human beings with each person being on a path of self-actualization. Secondly, a student's feelings and aspirations are respected with attention to the emotional side of learning, leading to the development of a student's positive self-concept and self-esteem, which in turn develops self-efficacy

\section{Research Methodology}

This research is qualitative. Communication is complex individual interaction. The complexity arises because it is naturally formed as diversity of individual, social, and cultural characteristics. Therefore, it is very interesting to analyze it in qualitative study. The subjects were women aged 25-50 years. The data obtained through observation and documentation. The collected data is analyzed and sorted by type of phatic speech act. In analyzing the data, it must connect to the context first. To get the maximum results in exploring phenomena that occur in women conversation, the researcher does not only see and understand the meaning, but rather in trying exploration to identify an event that appears either, and ethnography is used as a tool to approach data (Hammersley, Martyn Atkinson, 1983; Jensen \& Jankowski, 1991). In analyzing the data it applies Spreadly's theory. Based on his theory the ways to analyze the data are divided into 4 analysis: 1) domain analysis, 2) Taxonomy analysis, 3) Componential analysis, and 4) discovering cultural themes. Domain analysis is essentially an effort of researchers to obtain the 
social domain contained in the study site (Santoso, 2017). At the stage of domain analysis women is being a center of the anaysis, so in domain analysis women is the domain of the study. Phatic speech and politeness strategy are two fields that analyzed in taxonomy analysis. after doing taxonomy analysis, there will be some different results. The result of the analysis observed to get the specific thing. This process can be called as componential analysis. The last is discovering cultural theme. In this step the researcher gets the red line of the result of phatic speech act anlysis, politeness strategy analysis, and humanistic teaching. Credibility test conducted through extending observation and member check extension.

\section{Findings}

\subsection{Phatic Speech Acts}

Phatic speech acts aims to create and maintain the relationship between speakers and heares. The forms of phatic speech include greeting, thanking, asking for news and others. The act of speech implies a mere lip service, meaning that the speaker does not really mean the point in their speech. The following data is a form of phatic expression.

R1 : Jalan-jalan ke pasar beli buah atin...apa kabar bunda Titin...???

R2 : Buah duku buah alpukat...Alhamdulillah diriku sangat sehat...

R1 : Oh kirain buah duku ikan bakar..hahaa..gak nyambung...

R2 : Ikan bakar belinya di serayu...gmna kabar dirimu wong ayu?

The above data is the utterances of 2 participants. $\mathrm{R} 1$ is a housewife (50 years) who has a close relation with R2. R2 is (51 years) a housewife who has a higher social status than R1 because R2 is a former wife of high officials. Rlup dates her status "jalan jalan ke pasar beli buah atin...Apa kabar bunda Titin...????" (it is the expression of saying hello by asking the condition of hearer). It is phatic utterance because $\mathrm{R} 1$ asked the news $\mathrm{R} 2$ using pantun (ryhmes), then $\mathrm{R} 2$ responding to R1 by stating that she is healthy also in the form of pantun (rhymes). "Buah duku buah alpukat...alhamdulillah diriku sangat sehat...." The last comment of R2 "Ikan bakar belinya di serayu...gmna kabar dirimu wong ayu?" These utterances include phatic. As it is generally the Javanese culture, when someone asks the news, it should reply also ask news.

Moreover, R1responses by commenting using unproperly rhyme. "Oh kirain buah duku ikan bakar..hahaa..gak nyambumg...”. It includes phatic acts because R1 deliberately joking by making pantun (rhyme) in not appropriate rhyme. Phatic speech acts on the data seen from the utterances of the speaker and her partners who say to each other greeting news poem. The function of the speech is to strengthen friendships and create a harmonious relationship.

Phatic speech acts have an important role in friendship. The efforts to familiarize themselves with calling name using a special designation is also a marker of phatic. This is shown in the following data:

R3 : Bianglala, maafkan aku tak mampu mengartikan aneka warnamu kini.

R4: Met pg ce,..cece koq biang lala ciiihhhh hehe..

R3 :..lhow bianglala kan punya warna2 nan indah tuh, hiiikkz, beb

R5 :Oo...iya ky pelangi y ace...warna warni hehehe...

R3 : @ Amoy..., haiyaaaawlah Beib, warnanya kayak rainbow...

The data above is the coversation of 3 participants namely R3 55 years old. Her education is doctoral degree, R4 is 50 years old and R5 is 41 years old. The three speakers talk about R3's 
apology on her apology to a person called a bianglala. The utterance of R3 "Amoy:..lhow bianglala kan punya warna2 nan indah tuh, hiiikkz, beb" ( Lhow, the colorful rainbow is beautiful, isn't it?) It shows that the speaker does not want everyone knows what she said in her status. The word "hiiikkz, beb" is a phatic marker. It is a marker of phatic because speakers familiarize themselves with partners by using joking style. The call of "Beib" is also a marker of phatic to familiarize and establish a harmonious relationship. Another term used by adult women to call a speech partner as a marker of phatic are: (1) broou, (2) jeng, (3) mbak ayu, (4) bos, (5) wong ayu, (6) bu, (7) momy, (8) bunda, (9) jeung, (10) jeung cah ayu, (11 ) cantik, (12) mom ayu

Harmony is a feeling of feeling one sense and one word among members. It can be reflected in the attitude of mutual respect / love each other. The following data is a form of phatic that serves maintaining harmony.

S1 : Yiipi lgsg dpt bis depan kts...jarang2 begini nih....mantaaap

S2 : Berkat doa gw tuh kaqiiiiik=Dqiiik=Dqiiik

S1 : Kl gt doain lagi tik biar ada orang mau bayarin ongkos gw wkwkwkwkw..

S2 : Boleh...Tp isiiin pulsa sy dl rp 50 tp jgn di telp krn sy lg $M$ wkwkwk

S1 : Komen lo mengingatkan gw buat ntar malem nih tik...cari sop kambing dulu ahhh Ha...Ha...Ha...Pha...haha

S3 : Take care, momy.....

S1 : Tq di....sorry responding late.....)

The utterance "Tak care, momy...spoken by S3 is aimed to reply S1"s status, "Yiipi lgsg dpt bis depan kts...jarang2 begini nih..." (The expression of happiness occurred because she does not wait for bus a long after exiting her office). The utterance is phatic. It's function is to create harmony. The speaker prefers to use English expression. She knows well that S1 has the same educational study. They were graduated from faculty of letters English department, so she wants to show that she is care and friendly. The speech is impressed only as a form of greeting. The speakers signs that she does not want to communicate even longer. As Jacobson (1980) argues that phatic communication is an utterance used to begin, maintain, or disconnect communications.

Furthermore, Friendship / solidarity is a relationship between individuals or groups based on shared moral feelings and beliefs reinforced by shared emotional experiences (Johnson, 1986). The following data is a conversation conducted by 3 women who have a close relationship. The topic discussed is prayer and hope on Friday.

R6 : Meniti hari Jumat yang khidmat!! Semoga diberikan kelancaran dlm melaksanakan kewajiban. Dan buat sahabatku yang sedang sakit, smoga diberikan kesembuhan. Yg sedang dlm kesempitan, smoga diberikan kelapangan. Yg sedih, smga deberikan keceriaan. Yg sedang menjalankan amanah, smoga diberikan kekuatan. Yg sedang santai, smoga diberikan kesenangan yang berguna. Hidup terasa bermanfaan bila kita saling mendoakan $\wedge_{-} \wedge$

R7 : Amin $2 x$ ya robbal alamin

R8 : Amin $3 x Y R A$ 
The utterance spoken by $\mathrm{R} 7$ and R8 "Amin $2 x$ ya robbal alamin and Amin $3 x Y R A$ " is a phatic utterance. Speakers want to build good relationships among members in the same social and trust.

Finally, Sympathy is the process of someone interested in others so as to feel what is experienced, done and suffered by others (Soekanto, 2001). The following data is a phatic speech acts that serves to show sympathy:

R9 : Sedang berdoa semoga ada mukjizat .... Untuk ku .... Ammiiinnnn

R10 :Amin YRA ... Melu ndonga Wat ... Mugo2 terkabul semua yg terbaik untukmu ...

$\mathrm{R} 11$ :Amien ..... smg terkabul deh ya say

R9:Testi@Amiinnn.... YRA ....trmakasih tes....

R9 :Mbak Yanti@Amiiinnn ... trmakasih smga mbk Yanti jga terkabul ya......

R12 :Mukzizat apalagi Mb Watie ?.... semoga terkabul ... Amien

R9 :MbkUtik@Amiiiiinnnnn..... YRA .... Smga ya trmakasih bu humas kyuuu....

$\mathrm{R} 13$ :Amiiinnn...

R9:Rini @Amiinnn...trmakasih smga trkabul doa2 kita ya

Participant R 9 is a housewife with high school education background. She up dates status, "Sedang berdoa semoga ada mukjizat .... Untuk ku .... Ammiiinnnn" (She is praying to God hoping for the miracle, aameen)). R10 gives comment, "Amin YRA ... Melu ndonga Wat ... Mugo2 terkabul semua yg terbaik untukmu ..." (ameen, Hopefully Allah will give the best for you). R11 says, "Amien .... smg terkabul deh ya say" (ameen, may Allah grant your prayers). Next, it is the comment of R12. She is one of R9's friend in playing tennis. Her response is "Mukzizat apalagi Mb Watie ?... semoga terkabul ... Amien" (what more miracles? May be granted). R13 replied to the speaker's status by commenting, "Amiiinnn ...". The phrase Aamiin (aameen) is a phatic marker that describes the feelings of the patner's speech to try to understand what the speaker perceives in her status. The choice of the word "deh" in the speech "Amien ... .. smg terab ya yes" is also a marker of phatic. "Deh" contains the meaning of pretense / idiosyncratic expressions. While comments from other partners, "Mukzizat apalagi mbak Watie?... semoga terkabul ... Amien" is also just a small talk. Interrogative sentences conveyed by speakers mean that speakers are joking. Typically according to the ethics and norms of the people of Java it is categorized as taboo. The result of the phatic speech act analysis can be summarized as follow: 


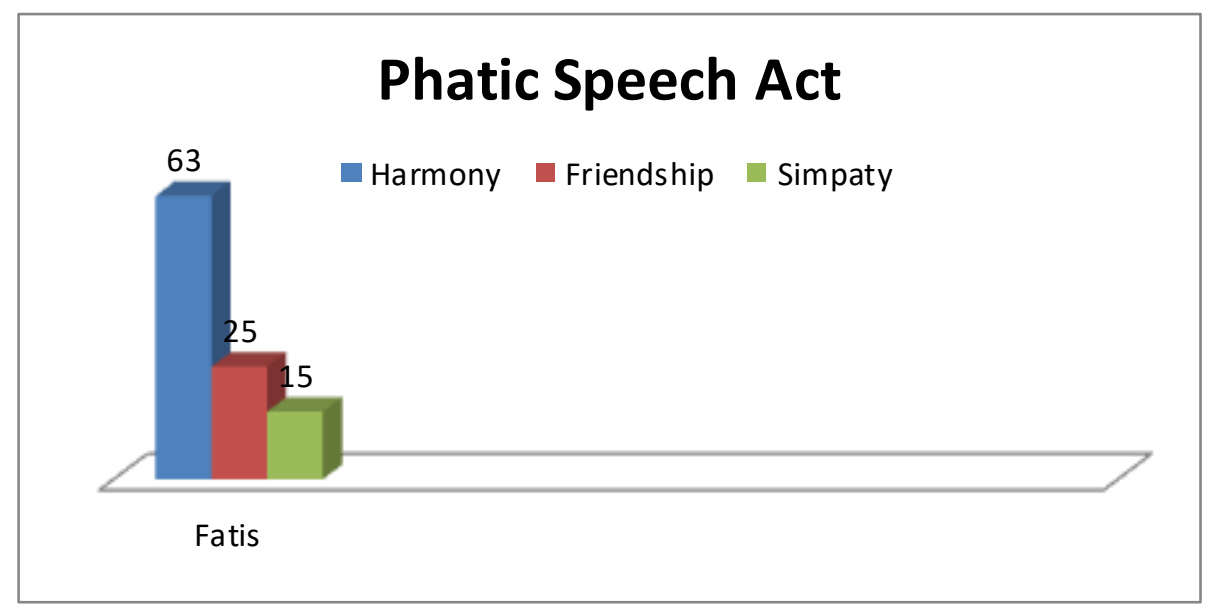

Figure: Phatic Speech Act

\subsection{Politeness}

After finding the phatic speech act, it is important to analyze politeness to observe more the relation of it in women communication on Facebook. The result of politeness strategies are below:

On the status of R1 "Jalan ke pasar beli buah Tin (walking to the market to buy fruit )... Apa kabar bunda Titin (how are you mom Titin)". This data show polite expression. It includes the positive politeness strategy where the speaker tries to attract attention with her jokes through the rhymes to her partner, so it is reflected that both are very familiar and has close relationship. The first comment from R2 "Buah duku buah alpukat...Alhamdulillah diriku sangat sehat..." including the positive politeness strategy where speakers try to attract attention with her joke to her partner. It is reflected that both are very familiar. The second comment from R1 "Oh kirain fruit duku ikan bakar..hahaa .. not nyambung ..." including positive politeness strategy where speakers use jokes to keep a chat with her partner. The last comment from R2 "Ikan bakar belinya di serayu...gmna kabar dirimu wong ayu?' Including the positive politeness strategy where speakers try to attract the attention of his partner said back by using a rhyme accompanied by praise and jokes to her partner, both are very familiar.

The second data, on the status of R3 "Bianglala, maafkan aku tak mampu mengartikan aneka warnamu kini" (Bianglala, forgive me not being able to interpret the various colors now) is a negative politeness strategy where the expression of apologizing is just a formality. The first comment from R4 "Met pgi ce,. , cece koq biang lala ciiihhhhh hehe ..." (morning sister, how could rainbow be?) is a positive politeness strategy where speaker asks certain reasons to the partners said. The second comment from R3 "@Amoy: ... bianglala kan punya warna2 nan indah tuh, hiiikkz, beb" is a positive politeness strategy where speaker gives a certain reason to her partner. The third comment from R4 "Oo ... ...iya ky pelangi y ace...warna warni hehehe..."is a positive politeness strategy where speaker gives certain reasons to their partner with joking, and the fourth Comment from R3 "@Amoy: ...haiyaaaawlah Beib, warnanya kayak rainbow...(the colour is like a rainbow ....)" is a positive politeness strategy where speaker gives certain reasons to their partners with a joke. 
The third data, the utterance of S1 "Yiipi lgsg dpt bis depan kts...jarang2 begini nih" can be categorized as positive politeness strategy in which speaker expresses her joy at the same time expressing the reason that she is enabled to attract other partners to comment. The first comment was written S2 "Berkat doa gw tuh kaqiiiiik=Dqiiik=Dqiiik". S2 responses include a positive politeness strategy in which she responds, recognizes and cares to S1 despite being delivered in jest. The second comment submitted by S1 "Kl gt doain lagi tik biar ada orang mau bayarin ongkos gw wkwkwkwkw.." is a positive politeness strategy where S1 agreed with S2 comment before, so she added a request to the S2 for the next activity. The fifth comment is written by S3 "take care, momy ... :)" where the speech shows the familiarity with the calling name "momy". The call is usually uttered to the close friend. In addition, the speech also shows the attention. So the speech goes into the category of positive politeness strategy. The third comment from S2 "B=oleh...Tp isiiin pulsa sy dl rp 50 tp jgn di telp krn sy lg $M$ wkwkwk" These include reducing the demand for S1. Although delivered in jest, she indirectly asked for rewards to her partner. The last comment was written by $\mathrm{S} 1$ "Tq di ... sorry responding late ..... :)" to respond to S3's previous words. S1's comment is categorized as Negative politeness strategy because the speech is intended to appreciate the opponent of her speech that has provided comments and good responses. However, the speech is focused on avoiding the embarrassment. S3 will experience if her speech is not responded by S1, So S1 said the word sorry, in other words $\mathrm{S} 1$ 's speech above only as a formality. In the fourth comment of S1 "Komen lo mengingatkan gw buat ntar malem nih tik...cari sop kambing dulu ahhh Ha...Ha...Ha...Pha...haha" contain offrecord politeness strategy because the intent of S1's speech has a subtle meaning and does not show relation with the previous speech, so her partner should be able to interprete her own meaning of the speech.

The fourth data, on R6 the status of R6 "Meniti hari Jumat yang khidmat!! Semoga diberikan kelancaran dlm melaksanakan kewajiban. Dan buat sahabatku yang sedang sakit, smoga diberikan kesembuhan. Yg sedang dlm kesempitan, smoga diberikan kelapangan. Yg sedih, smga deberikan keceriaan. Yg sedang menjalankan amanah, smoga diberikan kekuatan. Yg sedang santai, smoga diberikan kesenangan yang berguna. Hidup terasa bermanfaan bila kita saling mendoakan $\wedge_{-} \wedge$ " indicates an optimistic attitude, prayer, hope and attention to his friends who may be in a state of sickness, tightness, sadness, or relaxation. The speech also reflects an attempt to facilitate social relationships with other speech partners expressed through the prayers. So the utterance is categorized into the positive politeness strategy. The speaker tries to be close and warm to hearer. The first comment from R7 "amin3x ya robbal alamin ...." also contains a positive politeness strategy where in her speech indicates an agreement on R6's status by allowing what R6 has written, which means the speaker approves or has the same prayer and expectations like partners said. The last comment from R8 "Amien3x YRA" also contains a positive politeness strategy where her speech indicates an agreement on R6's status, by ensuring what R6 has written, which means that the speaker agrees or has the same prayer and expectation as his partner.

The last data, on the status of R9 "Sedang berdoa semoga ada mukjizat .... Untuk ku .... Ammiiinnnn" is a positive politeness strategy in which speaker expressed her hope to get a miracle. The first comment from R10 "Amin YRA ... Melu ndonga Wat ... Mugo2 terkabul semua yg terbaik untukmu ...Amin YRA ..." Is a positive politeness strategy where speaker pays attention to their partner by participating as well as positioning themselves as the state of his 
partner and guarantee what the hope of his partner said. The second comment from R11 "Amien .... smg terkabul deh ya say Amien ..." including positive politeness strategy where speaker uses the name calling 'say' as a marker of intimacy between them. The third comment from R9 "Test $i$ @ Amiinnn .... YRA ....trmakasih tes ... .. "is a positive politeness strategy where speaker shows the similarity of expectation with the hope of his partner by word aamiin she wrote. Then, the fourth comment from R9 "Mbak Yanti@Amiiinnn ... trmakasih trmakasih smga mbk Yanti jga terkabul ya....." is a positive politeness strategy where speaker expreses the similarity of expectation with the hope of her partner by saying aamiin she wrote. Next, R12's utterance "Mukzizat apalagi Mb Watie ?... semoga terkabul ... Amien" is a positive politeness strategy where speaker askes certain reasons to their partners about what was said before, and R9 replies"MbkUtik@ Amiiiiinnnnn ... .. YRA .... Smga ya trmakasih bu humas kyuuu ...." is a positive politeness strategy where speakers use the name calling" bu humas kyuu " which shows that there is closeness among them. The seventh commentary of R13 "Amiiinnn ..." includes a positive politeness strategy in which speaker showes their concern by ensuring what their partners hope to be. R9 closes the chating by commenting R13'utterance @ Amiinnn ... trmakasih smga trkabul doa kita" includes a positive politeness strategy in which speaker shows their attention by ensuring their mutual expectations.

\section{Discussion}

Women communicate on Facebook by some reasons. One of them is they want to be praised, to be respected, and to be loved. Women's ability to speak politely makes them easy to create enjoyful communication. Women tend to communicate with words that do not fit the context. in other words, the speaker does not make a relevant contribution to the topic of the conversation, and it indicates that women's utterances tends to polite. Phatics markers which are dominated by laughing / joking expressions (emoticons, hhe, hihihi, hehehe, cicicici, hahaha, ehmm, ngoeeeek, eng eng, ck ck ck, wk wk wk ...) are not related to the context of the speech context being discussed. This is done by women to avoid silence (Stenström \& Jørgensen, 2009). The utterance "Berkat doa gw tuh kaqiiiiik=Dqiiik=Dqiiik" dan "Kl gt doain lagi tik biar ada orang mau bayarin ongkos gw wkwkwkwkw...". The speech responded to the status of the speaker who expressed her pleasure when she left the office as soon as she found a bus passing in front of her office. The utterance violates the maxim of relevance because the commentary does not fit the topic and seems to be perfunctory, coupled with the phrase "qiiiiik = Dqiiik = Dqiiik". In his speech, the speaker wants to give attention to the speech partner even with comments that come out of the topic of discussion. The phrase makes the atmospher fresh and intimate. This joke has strengthened the theory that women still hold the principle of politeness (Attardo, 1993; Coates, 2016; Cockcroft, Bluett, \& Shuttleworth, 2008; Holmes, 1995; Jespersen, 1992; Robin, 1973; Tannen, 1990). It can be assumed that the characteristics of women politeness are clearly illustrated in phatic speech acts (Arndt \& Janney, 1985; Hill, Ide, Ikuta, Kawasaki, \& Ogino, 1986; Malmkjær, 2002; Obana \& Tomoda, 1994). The signs of positive politeness strategies are carried out by women such as: (1) giving praise, (2) showing empathy and sympathy, (3) giving attention, (4) avoiding disapproval, (5) joking clearly illustrated in the expression of phatic. This is corroborated by Levinson in Chaer (2010) a positive politeness strategy contributes to the formation of a speech act. The politeness strategy and the principle of cooperation in speech acts can be used (Nazir, 2012; Zegarac, 1998). Psychologically this is done because women have the nature of what is referred to as the feminine type, namely women have the nature of nurturing, 
caring, easy to adjust and sacrifice their own interests Charlotte Kohn-Behren in Simandjuntak (1984).

Rooted in constructivist social perspective, humanistic education tries to engage learners in interactional practices. In this regard, as Arnold (1998) remarks the educator should be able to create social relations together with a positive atmosphere in the classroom, and organize cooperative language work, by enhancing the learner's emotions and inner self. Pointed to the discussion above the women politeness in phatic speech acts can be used as a learning approach. Facebook is used by the women to communicate and build relationships. Through this interaction women are required to be able to please their Facebook friends. The desire of women to be cared for, loved and appreciated insist women to be able to choose good speeches and pleases their friends. This is in accordance with humanistic learning. This learning concept gives freedom to learners to choose how to learn something. Basically, humanistic theory is a learning theory that humanizes humans. Learning is centered on a person. This theory cannot be separated from education that focuses on how to produce something effective, how to learn that can increase creativity and utilize the potential that exists in a person. The success of learning according to this theory is when there is a desire from within a person to learn, know new information (Mckenna, Kear \& Ellsworth, 1995; Zhang \& Atkin, 2010).

Women's interaction on Facebook can be source of learning. They will realize the condition and judge something better to do. When she got unpleasant situation she will try to make pleasure. Based on the analysis, the positive politeness strategy is dominated applied by the women. Women express her feelings on Facebook using more indirect speech. Women have subtle feelings, so she will save her friend face. She will avoid face threatening act. The learning process in saving the face of the interlocutor in communication is the reflection of humanistic teaching. Underhill (2009) said there were 7 points that should be noted in humanistics teaching. In communication, speaker must consider to the way how to listen, the way how to speak, how to use of power and authority, the way to give attention to the processes in the group, manage our own attitudes and beliefs, the way how to show our inner state. These ways are very close relate with politeness.

\section{Conclusion}

Phatic speech acts carried out by women to establish and maintain good social relations. Phatic speech acts specifically found 3 functions, namely: maintaining harmony, friendship and showing sympathy. The implementation of women phatic speech acts on Facebook reflects polite speech. Women are more likely to apply positive politeness strategies. This is closely related to the nature of women who like to be friendly, avoiding conflict, and she likes to make small talk. The implementation of women phatic speech acts on Facebook reflects polite speech. Women are more likely to apply positive politeness strategies. This is closely related to the nature of women who like to be friendly, avoiding conflict, and she likes to make small talk. Furthermore, this is influenced by the psychology of women who are nurturing. Women prioritize friendship and maintain harmonious relationships in communication. This finding corroborates the theory of Leech (1993). Women's interaction on Facebook is a reflection of humanistic learning. The process of how to choose good speech, maintaining a good attitude to save the interlocutor's face, and organizing how to place our power and authority is a real learning process in accordance with the rules of humanistic learning. 


\section{References}

Adler, A. (1927). Understanding human nature. - PsycNET. Retrieved from https://psycnet.apa.org/record/1928-00537-000

Arévalo, C. M. (2014). A pragmatic and multimodal analysis of emoticons and gender in social networks.

Aries, E. J., \& Johnson, F. L. (1983). Close friendship in adulthood: Conversational content between same-sex friends. Sex Roles, 9(12), 1183-1196. https://doi.org/10.1007/BF00303101

Arndt, H., \& Janney, R. W. (1985). Politeness revisited: cross-modal supportive strategies. IRAL - International Review of Applied Linguistics in Language Teaching, 23(1-4), 281-300. https://doi.org/10.1515/iral.1985.23.1-4.281

Arnold, R. D. (1998). The Politics of Reforming Social Security. Political Science Quarterly, 113(2), 213-240. https://doi.org/10.2307/2657854

Assegaf, R. (2011). Filsafat Pendidikan Islam, Paradigma Baru Pendidikan Hadhari Berbasis Integratif-Interkonektif. Jakarta: PT Raja Grafindo Persada.

Attardo, S. (1993). Violation of conversational maxims and cooperation: The case of jokes. Journal of Pragmatics, 19(6), 537-558. https://doi.org/10.1016/0378-2166(93)90111-2

Aukett, R., Ritchie, J., \& Mill, K. (1988). Gender differences in friendship patterns. Sex Roles, 19(1-2), 57-66. https://doi.org/10.1007/BF00292464

Barbulet, G. (2013). Social Media- A pragmatic Approach: Contexts \&amp; Implicatures. Procedia - Social and Behavioral Sciences, 83, 422-426. https://doi.org/10.1016/J.SBSPRO.2013.06.083

Castells, M. (2000). The Rise of the Network Society (2nd ed.). Cambridge, MA: Blackwell Publishers, Inc.

Chaer, A. (2010). Sosiolinguistik Perkenalan Awal. Jakarta: Rineka Cipta.

Coates, J. (2016). Women, men and language: a sociolinguistic account of gender differences in language. London \& New York : Routledge

Cockcroft, S., Bluett, J., \& Shuttleworth, J. (2008). Living language and literature (2nd ed.). London: Hodder \& Stoughton Educational.

Dewey, J. (1997). Democracy and education: An introduction to the philosophy of education.

Duggan, M., \& Smith, A. (2013). Social Media Update 2013 | Pew Research Center.

Fardouly, J., Diedrichs, P. C., Vartanian, L. R., \& Halliwell, E. (2015). Social comparisons on social media: The impact of Facebook on young women's body image concerns and mood. Body Image, 13, 38-45. https://doi.org/10.1016/J.BODYIM.2014.12.002

Fardouly, J., \& Vartanian, L. R. (2015). Negative comparisons about one's appearance mediate the relationship between Facebook usage and body image concerns. Body Image, 12(1), 8288. https://doi.org/10.1016/j.bodyim.2014.10.004

Gage, N., \& Berliner, D. (1991). Educational psychology ((5th ed.)). Mifflin: Boston: Houghton.

Hammersley, Martyn Atkinson, P. (1983). Ethnography: Principles in practice. London: Tavistock.

Hill, B., Ide, S., Ikuta, S., Kawasaki, A., \& Ogino, T. (1986). Universals of linguistic politeness: Quantitative evidence from Japanese and American english. Journal of Pragmatics, 10(3), 347-371. https://doi.org/10.1016/0378-2166(86)90006-8

Holmes, J. (1995). Women, men and politeness. Retrieved from https://www.worldcat.org/title/women-men-and-politeness/oclc/30734505

Hopkins, K. (2014). The phatic nature of the online social sphere: Implications for public 
relations. PRism, 11(2), 1-12.

Jacobson, G. F. (1980). Crisis Theory. New Directions for Mental Health Services, 1980(6), 1-10. https://doi.org/10.1002/yd.23319800603

Jensen, K. B., \& Jankowski, N. W. (1991). A Handbook of Qualitative Methodologies for Mass Communication Research. London / New York.: Routledge.

Jespersen, O. (1992). The philosophy of grammar. Chicago: University of Chicago Press.

Johnson, D. P. (1986). Teori sosiologi klasik dan modern. Jakarta: Gramedia.

Khatib, M., Sarem, S. N., \& Hamidi, H. (2013). Humanistic Education: Concerns, Implications and Applications. Journal of Language Teaching and Research, 4(1), 45-51. https://doi.org/10.4304/jltr.4.1.45-51

Kivran-Swaine, F., Brody, S., \& Naaman, M. (2013). Effects of gender and tie strength on Twitter interactions. First Monday, 18(9). https://doi.org/10.5210/fm.v18i9.4633

Leech, G. (1993). Prinsip-prinsip pragmatik. Jakarta: UI-Press.

Lei, P.-W., \& Wu, Q. (2007). Introduction to Structural Equation Modeling: Issues and Practical Considerations. Educational Measurement: Issues and Practice, 26(3), 33-43. https://doi.org/10.1111/j.1745-3992.2007.00099.X

Locher, M. A. (2015). Interpersonal pragmatics and its link to (im)politeness research. Journal of Pragmatics, 86, 5-10. https://doi.org/10.1016/j.pragma.2015.05.010

Malmkjær, K. (2002). The linguistics encyclopedia (2nd ed.). Retrieved from https://www.worldcat.org/title/linguisticsencyclopedia/oclc/441719289\&referer=brief_results

Maples, M. F. (1979). A humanistic educator: Basic ingredients. The Humanist Educator, 17(3), 107-110. https://doi.org/10.1002/j.2164-6163.1979.tb00051.x

Maslow, A. H. (1943). A theory of human motivation. Psychological Review, 50(4), 370-396. https://doi.org/10.1037/h0054346

Mckenna, M. C., Kear, D. J., \& Ellsworth, R. A. (1995). Children 's attitudes A national toward reading: Reading Research Quarterly, 30(4), 934-956.

Miller, V. (2008). New Media, Networking and Phatic Culture. Convergence: The International Journal of Research into New Media Technologies, 14(4), 387-400. https://doi.org/10.1177/1354856508094659

Nazir, B. (2012). Gender Patterns on Facebook: A Sociolinguistic Perspective. International Journal of Linguistics, 4(3), 252-265. https://doi.org/10.5296/ijl.v4i3.1899

Obana, Y., \& Tomoda, T. (1994). The sociological significance of 'politeness' in English and Japanese languages - Report from a pilot study. Japanese Studies, 14(2), 37-49. https://doi.org/10.1080/10371399408727576

Reisman, W. M. (1990). Sovereignty and Human Rights in Contemporary International Law. The American Journal of International Law, 84(4), 866-876. https://doi.org/10.2307/2202838

Robin, L. (1973). Language and Woman's Place. Cambridge University Press, 2(1), 45-80. https://doi.org/10.1017/S0047404500000051

Ruckel, L. M. (2012). Self-Sexualization in Facebook Photographs, Self-Objectification, and Body Image. The State University of New York at New Paltz.

Simandjuntak, B. (1984). Pengantar psikologi perkembangan. Bandung: Tarsito.

Soekanto, S. (2001). Hukum Adat Indonesia. Jakarta: Raja Grafindo Persada.

Stenström, A.-B., \& Jørgensen, A. M. (Eds.). (2009). Young speak in a Multilingual Perspective. 
https://doi.org/10.1075/pbns.184

Tannen, D. (1991): You just don't understand. Women and men in conversation. Sintagma: revista de lingüística; Vol.: 4. 4.

Theodoropoulou, I. (2015). Politeness on Facebook. Pragmatics, 25(1), 23-45. https://doi.org/10.1075/prag.25.1.02

Tiggemann, M., \& Slater, A. (2013). NetGirls: The Internet, Facebook, and body image concern in adolescent girls. International Journal of Eating Disorders, 46(6), 630-633. https://doi.org/10.1002/eat.22141

Underhill, P. (2009). Why we buy: the science of shopping. Retrieved from https://www.worldcat.org/title/why-we-buy-the-science-ofshopping/oclc/893688260\&referer=brief_results

Valentini, C., \& Kruckeberg, D. (2012). New Media Versus Social Media: A Conceptualization of their Meanings, Uses, and Implications for Public Relations. In New Media and Public Relations, 3-12.

Wang, R., Bianchi, S. M., \& Raley, S. B. (2005). Teenagers' Internet Use and Family Rules: A Research Note. Journal of Marriage and Family, 67(5), 1249-1258. https://doi.org/10.1111/j.1741-3737.2005.00214.x

Wellman, B., \& Hampton, K. (1999). Living networked in a wired world. IEEE Intelligent Systems and Their Applications, 14(1), 15-17.

Wood, J. T., \& Inman, C. C. (1993). In a different mode: Masculine styles of communicating closeness. Journal of Applied Communication Research, 21(3), 279-295. https://doi.org/10.1080/00909889309365372

Wright, P. H., \& Scanlon, M. B. (1991). Gender role orientations and friendship: Some attenuation, but gender differences abound. Sex Roles, 24(9-10), 551-566. https://doi.org/10.1007/BF00288413

Wulandari, S. (2014). Speech Act Analysis on Facebook Statuses Used by Students of Muhammadiyah University of Surakarta. Universitas Muhamdiyah Surakarta, Surakarta.

Zegarac, V. (1998). What is "Phatic Communication"? In Current Issues in Relevance Theory (p. 327). https://doi.org/10.1075/pbns.58.14zeg

Zhang, L., \& Atkin, C. (2010). Conceptualizing Humanistic Competence in the Language Classroom by TJP - A Chinese Case. International Education Studies, 3(4), 121-127. https://doi.org/10.5539/ies.v3n4p121 